\title{
DIVORCE: STANDING TO "DIRECTLY" ATTACK SISTER-STATE DECREE DOES NOT DEPEND UPON DOMICILE IN THE FORUM AT DATE OF THAT DECREE
}

In Meeker $v$. Meeker ${ }^{1}$ the New Jersey Supreme Court held that a Mexican ex parte divorce may be attacked by a New Jersey domiciliary in a New Jersey proceeding instituted solely for that purpose despite the fact that as of the date of the divorce decree neither spouse had ever been a domiciliary of New Jersey. After six years of marriage the Meekers separated, Mrs. Meeker becoming domiciled in England and Mr. Meeker in the Phillipine lslands. In $1958 \mathrm{Mr}$. Meeker obtained an ex parte divorce in Mexico. Mrs. Meeker thereafter established permanent residence in New Jersey and brought suit to have the Mexican divorce declared null and void. The trial court dismissed on the grounds of lack of jurisdiction over the subject matter. The New Jersey Supreme Court reversed, purporting to overturn the venerable New Jersey precedent, apparently common to other states which have considered the issue, ${ }^{2}$ that standing to "directly" attack a sisterstate divorce depends upon the attacker's having been domiciled in the attack forum as of the date of the divorce. ${ }^{3}$

Domicile has traditionally been held a constitutional prerequisite to the granting of a divorce. ${ }^{4}$ Even an ex parte decree is entitled to full faith and credit ${ }^{5}$ as to the issue of status if obtained by a party domiciled in the issuing state. ${ }^{6}$ On the other hand, a court lacks jurisdictional power to adjudicate the marital status of parties both of whom voluntarily appear and consent to jurisdiction

\footnotetext{
152 N.J. 59, 243 A.2d 801 (1968).

${ }^{2}$ California, Connecticut, the District of Columbia, New York and Wisconsin.

${ }^{3}$ It seems probable that this rule is a reflection of early theories of divorce jurisdiction. See Haddock v. Haddock, 201 U.S. 562 (1906); Atherton v. Atherton, 181 U.S. 155 (1901).

4 Williams v. North Carolina, 325 U.S. 226, 229 (1945).

s U.S. ConST. art. 1V, § 1; see 28 U.S.C. $\S 1738$ (1964); Act of May 26, 1790, 1 Stat. 122.

${ }^{6}$ Williams v. North Carolina, 317 U.S. 287 (1942).
} 
if neither of the parties is domiciled in the forum-state.' Furthermore, the test of domicile which must be satisfied is not one merely prescribed by the forum-state, but rather one which must conform to a minimum constitutional standard. ${ }^{8}$ An ex parte proceeding based on domicile is only entitled to full faith and credit as to status, however, and cannot finally determine the financial responsibilities of the parties since a property adjudication in the absence of personal jurisdiction would be a denial of due process.? Moreover, an ex parte decree based upon domicile of one of the parties may always be attacked collaterally in another state by the absent party on the jurisdictional ground that the party obtaining the decree was not in fact domiciled in the issuing state. ${ }^{10}$ Subject to these avenues of attack, however, domicile of the petitioning party in the forum-state is a totally sufficient jurisdictional basis for a decree of divorce.

Present domicile alone, however, has not been considered an adequate jurisdictional basis for parties wishing to attack a sisterstate divorce decree. Indeed, most states have refused, except under limited circumstances," to permit such an attack unless the attacker was domiciled in the attack-forum state at the time the divorce decree was rendered. ${ }^{12}$ In New Jersey, an ex parte divorce defendant was deprived of standing to attack the decree unless the attack was truly "collateral"13 - arising in a proceeding which sought

\footnotetext{
'Alton v. Alton, 207 F.2d 667, 677 (3d Cir. 1953).

Id.

${ }^{\circ}$ New York Life Ins. Co. v. Dunlevy, 241 U.S. 518 (1916); Hart v. Sansom, 110 U.S. 151 (1884); Pennoyer v. Neff, 95 U.S. 714 (1877).

to Williams v. North Carolina, 317 U.S. 287 (1942).

" E.g., De Young v. De Young, 159 P.2d 102 (Cal. App. 1945), affd on other grounds, 27 Cal. 2d 521, 165 P.2d 457 (1946) (husband prevented his wife from obtaining knowledge of his divorce action); Santangelo v. Santangelo, 137 Conn. 404, 78 A.2d 245, cert. denied, 341 U.S. 927 (1951) (husband prevented his alien wife from gaining entry into the United States until after he had obtained his divorce).

${ }^{12}$ See, c.g., Curley v. Curley, 120 F.2d 730 (D.C. Cir.), cert. denied, 314 U.S. 614 (1941); Morrissey v. Morrissey, 1 N.J. 448, 64 A.2d 209 (1949); Floyd v. Floyd, 95 N.J. Eq. 661, 124 A. 525 (Ct. Err. \& App. 1924); Bell v. Cross, 231 N.Y. 329, 132 N.E. 106 (1921); Denkman v. Denkman, 172 Misc. 57, 14 N.Y.S.2d 450 (Sup. Ct. 1939); Standish v. Standish, 179 Misc. 564, 40 N.Y.S.2d 538 (Dom. Rel. Ct. 1943). But see, e.g., De Young v. De Young, 159 P.2d 102 (Cal. App. 1945), affd on other grounds, 27 Cal. 2d 521, 165 P.2d 457 (1946); cf. Santangelo v. Santangelo, 137 Conn. 404, 78 A.2d 245, cert. denied, 341 U.S. 927 (1951); In re Gibson's Estate, 7 Wis. 2d 506, 96 N.W.2d 859 (1959).

${ }^{13}$ Morrissey v. Morrissey, I N.J. 448, 64 A.2d 209 (1949); Floyd v. Floyd, 95 N.J. Eq. 661, 124 A. 525 (Ct. Err. \& App. 1924); Shapiro v. Shapiro, 13 N.J. Misc. 788, 180 A. 434 (Ch. 1935); Fried v. Fried, 99 N.J. Eq. 106, 132 A. 674 (Ch. 1926).
} 
relief such as alimony or separate maintenance and which necessitated the incidental nullification of the prior divorce in order to be successful. ${ }^{4}$ A "direct" attack-one seeking nullification of the prior divorce by the New Jersey courts as its sole relief" prohibited. ${ }^{16}$ The exclusion of "direct" attacks was based upon a belief that if the attacker was not domiciled in New Jersey when the sister-state divorce was rendered, there was no "marital res" within New Jersey nor fraud upon the New Jersey courts which would provide a basis for jurisdiction over a suit attacking the sister-state decree. ${ }^{17}$ It was further feared that in the absence of such a rule New Jersey would become a "mecca for disgruntled divorcees." 18 The Meeker court, by adopting a choice-of-law rule requiring imposition of the law of the state in which the attacker was domiciled as of the date of the divorce, dispelled the fear that its holding would turn New Jersey into such a "mecca." This choice of law limitation removes any incentive to forum shop based on the defendant's desire to avail himself of whatever comparative advantages New Jersey's law might provide him as opposed to the law of his previous domicile. ${ }^{19}$ Relying on the supposition that domicile in fact of either spouse offers a sufficient jurisdictional basis to grant a divorce, ${ }^{20}$ the New Jersey court concluded that present domicile in New Jersey was an adequate jurisdictional base for a suit attacking a foreign decree of divorce. ${ }^{21}$ The court further reasoncd that if the divorce was a fraud upon a genuine New Jersey domiciliary, then the courts of New Jersey had a sufficient interest in her marital status to justify intervention..$^{22}$

The significance of the Meeker decision would seem to lie in its conclusion that a state has a sufficient basis to exercise jurisdiction over a suit attacking an ex parte sister-state divorce if the attacker is domiciled in the attack-forum state at the time the attack is brought. Except for a few cases, distinguishable because of their

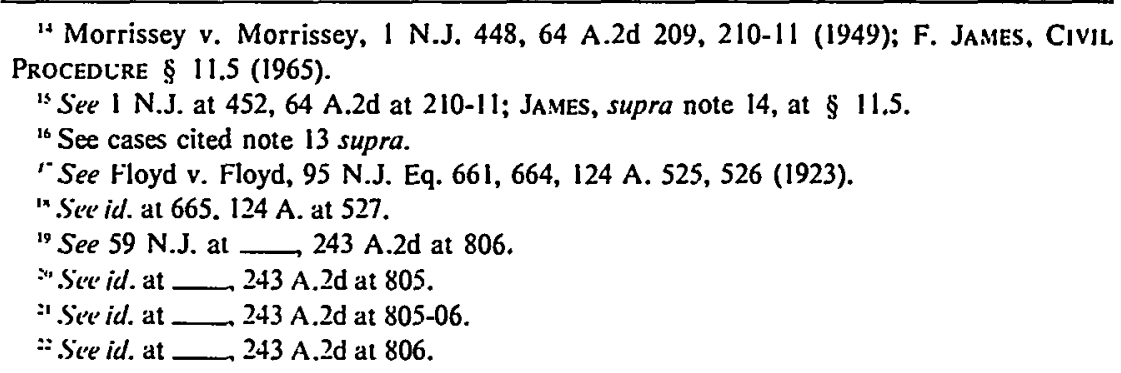


bizarre factual situations, ${ }^{23}$ Meeker is the first case to so hold. The Supreme Court has apparently never dealt with the question of whether the domicile of an individual is relevant to his standing to attack an ex parte divorce. There is little difficulty in justifying a finding of jurisdiction in the Meeker case, however, since if present domicile of one of the parties is a sufficient jurisdictional basis for a decree of divorce it should be equally sufficient for an action to establish the continued validity of a marriage. Moreover, since the plaintiff had become a genuine domiciliary of New Jersey, and since the state in which she had been domiciled on the date of the divorce no longer had a substantial interest in the marital relationship, arguably New Jersey stood as the state most concerned with the plaintiff's marital status. ${ }^{24}$ This seems to be the approach taken sub-silentio by the New Jersey Supreme Court in emphasizing that every "Meeker" plaintiff will be subjected to intense scrutiny concerning the genuineness of his New Jersey domicile. ${ }^{25}$ The court's decision to apply the substantive law of the state of the attacker's domicile as of the date of the divorce is arguably justifiable because it recognizes that as of the date of the divorce New Jersey had no interest in the marriage, albeit New Jersey now has the superior interest. While New Jersey's present superior interest might logically justify applying New Jersey law regarding the validity of the ex parte decree, such a contention must fail upon recognition of the grave danger of forum-shopping which such a policy would create.

Apart from the Meeker court's determination that present domicile constitutes a sufficient basis for jurisdiction lies the court's apparent implication that domicile of the attacker in the attackforum state when the attack is brought is an absolute prerequisite to jurisdiction over a suit attacking an ex parte divorce decree. There is language in several cases which seemingly supports such a position. ${ }^{26}$ The requirement of domicile in the forum-state as a prerequisite to divorce jurisdiction is based upon the strong and unique interests which the state or states in which the spouses are

"See cases cited note 11 supra.

3 See, e.g., Williams v. North Carolina, 317 U.S. 287, 298-99 (1942).

2s See 59 N.J. at $\longrightarrow 243$ A.2d at 806 .

${ }^{6}$ See, e.g., Estin v. Estin, 334 U.S. 541, 546-47 (1948); In re Chong Jah Alix, 252 F. Supp. 313, 314 (1965); Turpin v. Turpin, 175 So. 2d 357, 359 (La. App. 1965); Sharp v. Sharp, 416 S.W.2d 691, 696 (Mo. App. 1967). 
domiciled have in their marital status. ${ }^{27}$ Protection of offspring, property interests, and the enforcement of marital responsibilities are but a few of the commanding problems in the field of domestic relations with which the state must deal. ${ }^{28}$ Inasmuch as these interests are vitally affected whether the issue is severance of a marital relationship or reinstatement of a previously severed relationship, the reasons for requiring domicile as the basis for jurisdiction in the former case are as compelling in the latter. It cannot forcefully be contended that interests which are of such great import to a particular state should be left to the mercy of wholly disinterested jurisdictions. Nor can the fact that a suit attacks rather than seeks a divorce be enough to justify a different standard. As the court in Meeker properly realized, however, it does not seem logical or necessary to extend the general requirement of domicile to the point of requiring such domicile as of the date of the divorce as a prerequisite to jurisdiction over a suit attacking an ex parte divorce. Whatever interests which the state of prior domicile or its citizens may have can be adequately protected by applying the law of that state in any attack suit. Viewed in this light; Meeker satisfactorily balances the interests of the attacker's domicile as of the date of the divorce with the interests of his present domicile. It further permits individuals the maximum freedom to alter their marital relationships consistent with the legitimate interests of the various states and parties involved in the controversy. 


\section{INTENTIONAL BLANK}


. 